commercial services consumes purchasable credits. This is another important financial detail that Mr. Fu glossed over or left out.

Chapter Ten is focused on building custom web apps with a map component. Web applications are dependent on an orchestration of database, back-end server, and front-end client components, and $\mathrm{Fu}$ takes the time to explain how this orchestration is effected. He does a really good job of providing basic building blocks, as well as touching on important topics for learning both how to program in any language and how to use the Esri ArcGIS for JavaScript API. Different front-end programming languages can be used to address different roles in web application development, and the author makes their different strengths clear. In describing the ArcGIS for JavaScript API, the author particularly discusses classes, methods, and properties, all of which are important programming concepts. There are informative discussions of both debugging and of Esri's Sandbox-both are valuable troubleshooting tools. The online Sandbox (developers.arcgis.com/javascript/latest/ sample-code/sandbox/index.html?sample=get-startedmapview) is both a JavaScript map app testing environment and a great source for sample code.

\section{FINAL THOUGHTS}

Getting to Know Web GIS, Third Edition covers enough detail on a wide range of web GIS topics to pique the interest and hold the attention of anyone wanting to make maps in an online environment.

I think that this is an ideal book for use in a GIS classroom where the curriculum is focused on Esri technology. With teaching aids-PowerPoint slides and sample dataavailable on the web, instructors are also given a leg up putting together content for any new web GIS class.

This book is also an appropriate resource for a GIS analyst in an Esri shop who has been asked to build GIS-based web apps, but has little or no previous background in web development. In my experience, there are many shops that find that they have to move quickly to meet new challenges in web and mobile mapping, and must do so without the luxury of additional hires. Getting to Know Web GIS, Third Edition should help any experienced mapping hand get a grasp on the new tools and environment.

\title{
THEATER OF THE WORLD: THE MAPS THAT MADE HISTORY
}

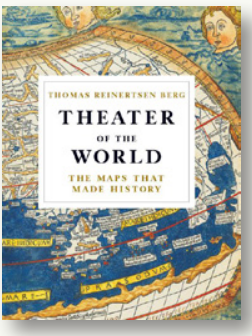

By Thomas Reinertsen Berg; translated from the Norwegian by Alison McCullough

Little, Brown and Company, 2018

367 pages, 55 color illustrations; $\$ 35.00$, hardcover.

ISBN: 978-0-316-45076-8

\section{Review by: Carolyn Hansen, Stony Brook University}

In this work, Thomas Reinertsen Berg provides a broad survey of the history of mapmaking-from prehistoric images carved into the physical landscape to dynamic digital maps. As he explains in his introduction, the author emphasizes that maps hold importance as historical artifacts that tell a story about the lives of the people and societies who created them. He sees maps as not only representations of physical space, but also as depictions of cultural values and judgments made manifest by what is deemed worthy of inclusion. One of Berg's key ideas is that the history of maps is akin to the history of society, and that while maps serve a variety of practical purposes they also reflect the age in which they were created. Similarly, any reading of either history or maps will also reflect the age and environment in which that reading takes place. He also argues that, just like the maps themselves, his own analysis in Theater of the World is very much a product of his personal experiences and environment, and attributes his book's heavy focus on the mapping of the northern areas of the world-particularly on Norway and Scandinaviato these factors.

The book is divided into ten chapters. The earlier chapters follow a rough chronological order, while the later ones are more thematically organized.

The first chapter, "The First Images of the World," deals with prehistoric maps, and begins with a map that was carved in stone sometime around the year $1000 \mathrm{BCE}$ in Bedolina, Italy. The Bedolina Map is not geographically accurate in its depiction of houses, fields, animals, and people-nor was it widely considered a map until the 1930s. Berg uses the Bedolina Map to discuss the concept of mapping itself from a theoretical perspective. What is 
it, he asks, that ultimately makes a map different from other types of images? He acknowledges that scholars disagree on what constitutes a map, and argues that the Bedolina Map should be seen as a symbolic, rather than a physically accurate, representation of space, and thus a representation that fulfills a variety of societal needs. The author turns next to the religious aspects of prehistoric maps, and discusses what he refers to as "Maps of the Dead" (10) such as celestial maps and maps used for ritualistic purposes. One example cited is a ceremonial drum confiscated in the eighteenth century from the indigenous Sami people of Lapland, decorated with a map depicting the Sami worldview (14-15). In this chapter, Berg also explores significant early mapmaking artifacts from the Babylonians, Sumerians, and Egyptians-including a map of the Babylonian world that was inscribed by Babylonians on a clay tablet over 2,600 years ago, and that showed, among other things, the first indications of the cardinal directions of east, west, and north.

In "Like Frogs about a Pond," his second chapter, Berg focuses on Greek mapmaking-particularly that of Claudius Ptolemy, the astronomer and mathematician who, in about $150 \mathrm{CE}$, wrote the famous Geographike Hyphegesis (Geographical Guidance, or Geography). Berg argues that Ptolemy's work was the culmination of Greek geographical thought, drawing on the work of earlier scholars such as Herodotus, Aristotle, and Eratosthenes. Berg explores the theories of these philosophers and describes the importance of Ptolemy's Geography, and he writes that Ptolemy made groundbreaking contributions to the theory of map projections. Despite the fact that Geography did not contain any new geographic information, it was nonetheless a pioneering first attempt at a comprehensive work on geography, and it served as an authoritative source for mapmakers through the Middle Ages and into the Renaissance.

The "Holy Geography" chapter explores the shift from practical mapmaking, such as that seen in Roman city maps, to Christian mapmaking, the purpose of which was grounded in the Augustinian idea that humans should understand the Earth in order to better understand the Bible. Berg argues that as a result of the decline in travel and geographic expeditions during the Middle Ages, Christian maps did not have any new scientific information to share, but instead focused on God's dominion over Earth. To illustrate this point, Berg provides the example of the English Hereford Mappa Mundi, created sometime around the year 1300. Drawn on calfskin, the map is centered on Jerusalem and presents the world as a round land mass surrounded by otherworldly beings, representing the spiritual realm. Berg argues that the purpose of Christian maps was to transmit a Christian interpretation of history, of ethnology, and even of zoology. In this chapter, he also describes the rise of nautical charts in the Later Middle Ages as a practical counterpoint to Christian mapping. Where a Christian map informed its reader about the metaphysical world, the navigational chart dealt with getting from place to place. The Carta Pisana, for example - the world's oldest surviving nautical chart, dating from around 1275-locates as many as 927 named places, and covers an area that stretches from Lebanon in the east to Morocco and England in the west.

"The First Atlas" chapter comes next, and focuses on the European Renaissance rediscovery of Ptolemy. It describes how mapmakers both copied Ptolemy's maps and used his lists of geographic coordinates to create new maps. One example Berg cites is the Cosmographiae Introductio, published in 1507 by the German cartographer Martin Waldseemüller. Conceived as a new version of Ptolemy's Geography, Waldseemüller's work was the first to break with what was until then the established opinion that the recently discovered lands in the western Atlantic were a part of Asia-according to Waldseemüller, this land he called America was an island that represented a new, fourth, part of the Earth. Later in this chapter, Berg describes the 1347 Lucas Brandis map of the German city of Lübeck, contending that it was the first modern printed map because it was based on eyewitness accounts and evidence as opposed to relying on existing sources from the Classical and Biblical eras. He also details how Abraham Ortelius assembled the first atlas, Theatrum Orbis Terrarum (1570), by soliciting maps from his personal network of cartographers and redrawing them in a standardized manner. Berg argues that this atlas was the first attempt at a comprehensive, standardized view of the world and that it led to a rise in scientific and experience-based mapmaking.

In Chapters Five and Six, Berg explores the rising business of cartography through the movement of maps across Europe throughout the sixteenth and seventeenth centuries. During this period cartographers became business rivals, and the mapmaking trade came to focus increasingly on particular markets. Thus, maps created for traders sailing the Mediterranean or Baltic Seas, for example, came to be quite different from maps for the military, or civil administration maps. The author also describes the importance of triangulation surveys and their influence 
on national mapping in Europe. For example, the Carte de France corrigée (Corrected Map of France) - the first nation-wide mapping project employing triangulation methods-was published in 1682 by Jean Picard, and sparked considerable controversy in that France was shown to be about twenty percent smaller than had previously been believed. Berg also writes about the British Ordnance Survey and the pre-Napoleonic Franco-British triangulation efforts. The modern mapping of Norway-an undertaking that began in 1779-and the mapping of Denmark are both explored in Chapter Six.

Chapter Seven narrates the mapping of the Far North, the roots of which he traces back to the Viking narratives recorded in the Sagas. However, he notes that the systematic mapping of the polar regions did not begin until the seventeenth century, when Europeans began searching for the Northwest Passage and the Northern (or Northeast) Sea Route. He discusses the many English expeditions and discoveries, such as Henry Hudson's in 1610 and William Baffin's in 1615-of Hudson Bay and Baffin Island, respectively-as well as the numerous Russian expeditions to the Bering Strait, Sea of Okhotsk, and Chukchi Sea. The late nineteenth century Norwegian mapping expeditions lead by Harald Sverdrup get some particular attention. Sverdrup's belief that a number of Arctic islands-including Greenland, Jan Mayen, Svalbard, as well as Ellesmere, Axel Heiberg, and others to the west of Greenland-rightly belonged to Norway introduces Berg's discussion of the role of nationalism in exploration and mapping, and the use of land claims a means of acquiring and maintaining political power.

Chapter Eight describes the systematic development of maps based on aerial photographs, beginning with the work that French Captain Georges Bellenger carried out in 1914 and 1915. Berg writes that it was aerial photography that provided the most current and accurate maps for military purposes during World War I, and that the extensive airphoto-based project to map Norway in the early 1930s was largely inspired by the wartime example. By contrast, the author writes that no significant air-mapping breakthroughs were made in World War II, though the war did show the United States how far they were behind many other countries in this area. As soon as the war ended, the United States military began an intensive project to map Europe from the air before diplomatic and political considerations could prevent them from doing so.
The history of underwater mapping is the topic of Chapter Nine-and takes early nautical charting and the late-nineteenth-century Norwegian expeditions in the North Sea as starting points. Berg argues that a critical milestone in underwater mapping was the 1956 publication of Marie Tharp and Bruce Heezen's physiographic diagram of the floor of the Atlantic Ocean, which was drawn in a way to mimic the appearance of an aerial photograph. This was the first map of its kind, and, despite some geographical inaccuracies, it proved extremely popular with both geologists and the public. The map's popularity led to an increased interest in underwater mapping, and to new and improved technologies such as sonar and satellite-based sensors that allowed oceanographers to create ever more accurate images. Despite these breakthroughs, however, the process of underwater mapping remains tedious and difficult, and as a result, the mapping of the world's ocean floor remains incomplete.

The final chapter of Theater of the World explores maps in the Digital Age, arguing that the foundations for most of our current technology lie in scientific breakthroughs in fields like satellites and computing that were brought about by Cold War mapping activities. The author's discussion of the rise of various mapping technologies- such as GPS, GIS, online maps, and Google Earth-places each in a persuasive historical context. Beyond that, Berg argues that although maps created with these technologies may seem extremely different from early maps created by prehistoric peoples, all maps share the common purpose of presenting a worldview. Furthermore, because that worldview will eventually, and inevitably, change, Berg also contends that maps share the commonality of obsolescencewhile any map may be the most current representation of the world at the time of its creation, over time every up-todate map is transformed into a historical artifact.

Throughout his book, Berg provides sound analysis, reasoned arguments, and strong examples to support his assertions. The book is extremely well researched and clearly written. It is accessible to a general audience, and would be of interest to anyone who enjoys history or maps. While Berg acknowledges that no one can write a book covering all of the history of mapmaking, Theater of the World provides an excellent foundation in the general history of mapmaking in Europe, and the history of Norwegian mapmaking in particular. 